\title{
91 University of Glasgow
}

Paul, F. C. (2018) Deep entanglements: history, space and (energy) struggle in the German Energiewende. Geoforum, 91, pp. 1-9.

(doi: 10.1016/j.geoforum.2018.02.017)

The material cannot be used for any other purpose without further permission of the publisher and is for private use only.

There may be differences between this version and the published version. You are advised to consult the publisher's version if you wish to cite from it.

\section{http://eprints.gla.ac.uk/158698/}

Deposited on 12 March 2018

Enlighten - Research publications by members of the University of

Glasgow

http://eprints.gla.ac.uk 


\title{
DEEP ENTANGLEMENTS: HISTORY, SPACE AND (ENERGY) STRUGGLE IN THE GERMAN ENERGIEWENDE
}

Franziska Christina Paul, School of Geographical and Earth Sciences, University of Glasgow

\begin{abstract}
This paper contributes to recent debates in energy geography, especially to energy transition research and literature, by developing a critical and empirically grounded understanding of energy transitions as expressions of contentious socio-spatial politics, past and present. The paper argues that historical struggles and contentious political practices around energy, so called energy struggles, continue to inform the ongoing and dynamic socio-spatial politics of energy transitions today and often manifest themselves in transition narratives. This analysis is supported by qualitative empirical materials derived from recent fieldwork in Berlin, Germany, which was conducted within the broader left-green movement for a socioecological and democratic German Energiewende. A historicisation of contentious politics and energy struggles facilitates an empirically robust framing of energy transition projects as dynamic, multi-actor, and more than eco-technical processes. The paper's contribution to energy geographies is threefold; firstly, utilising an empirically robust and historically sensitive analysis of the German Energiewende, the paper explores the deep entanglements of history, space and struggle in energy transitions. Secondly, the paper emphasises the need to understand energy transitions as constituted by energy struggles and contentious politics, past and present. Thirdly, the paper examines emergent spaces of energy democracy as part of the Energiewende and explores recent energy democracy demands as a spatial politics of energy transitions.
\end{abstract}

Key words: Energy geographies, energy transition, Energiewende, energy struggles, energy 
democracy, spatial imaginaries

\section{Introduction}

With the increase of public debates around climate change and geopolitical resource conflicts, energy - as both concept and object of study - holds renewed prominence in the social sciences (Huber, 2015; Juisto, 2009). Human geography, too, has seen a small renaissance of energy-related research over the past half decade which has begun to re-explore energy's relation to space (Bridge et al, 2013). Energy transitions in particular have become an important research topic for human geographers, potentially linking (geo)political, environmental, developmental, urban, rural and economic strands of the discipline in complex and dynamic ways. However, recent critiques cite a lack of critical social and political theorising towards energy and wider sustainability transition research within human geography (Becker et al, 2016; Huber, 2015; Juisto, 2009). Following this line of argument, this paper proposes to engage with energy transitions as social, cultural and political projects as much as eco-technical transformations, thus becoming dynamic, multiple and contested. Through drawing on qualitative research and empirical materials from the German Energiewende, this paper argues that energy transitions are constituted through energy struggles, past and present, which are characterised by a wider critical and socio-political engagement with the ownership, organisation and resource preference of energy within society.

I argue that an acknowledgement of both the rich histories of struggle and the spatial politics of contemporary energy transition projects allows for a more differentiated understanding of energy transitions as dynamic, politically transformative, spatial, and often 
contentious in practice (see also: Bridge et al, 2013). An emphasis on energy struggle and contentious histories challenges conceptualisations of transition projects as predominantly temporal, linear, and abstracted from (past) socio-spatial contestation (cf. Loorbach \& Rotmans, 2010; Seyfang et al, 2014). Furthermore, the notion of struggle contributes a critical element to transition studies and highlights the social and political possibilities arising from the spatial organisation of energy systems and infrastructures. The paper argues that historical struggles and contentious political practices around energy continue to inform the ongoing and dynamic socio-spatial politics of energy transitions today, and are tightly woven into both activist and broader socio-cultural understandings of the German Energiewende. This analysis is supported through qualitative empirical materials derived from recent fieldwork in Berlin, Germany, which was conducted within the broader left-green movement for a socio-ecological and democratic German Energiewende.

The paper is structured into four main sections followed by a conclusion. The next section highlights some of the shortcomings of energy geographies and transition literatures and proposes to study spaces of energy transition through exploring the rich histories of energy struggles as part of transition trajectories. The third section utilises empirical materials from the German Energiewende to explore different cuts through the wider left-green movement, including the rich histories and spatial politics of the Energiewende project, highlighting the deep entanglements of history, space and struggle as part of transition politics. The fourth section engages with the notion of struggle as constituting energy transitions and explores the inherent social, political, and often contentious character of energy transitions. The fifth section then examines emergent spaces of energy democracy as an expression of the spatial politics of energy transition projects, which address demands for more socially just and democratically accountable sustainability transitions, by drawing on 
the case example of the Berliner Energietisch (Berlin energy roundtable) campaign.

\section{Towards a Socio-Historical Spatial Politics of Energy Transitions}

Debates around climate change, energy scarcity and security, and geopolitical resource conflicts have firmly placed energy, as concept and object of study, back on academic research agendas. Human geographers have begun to think through energy and energy

transitions more spatially (see e.g. Becker et al, 2016; Bridge et al, 2013; Coenen et al, 2012), variously engaging with case studies of low carbon transition management (Geels, 2011; Raven et al, 2012) and community energy studies (Hargreaves et al, 2013; Seyfang et al, 2014; Walker et al, 2010). There have also been highly relevant critiques of an increasing neoliberalisation and commodification of nature in relation to energy (Castree, 2008a; 2008b; Juisto, 2009; McCarthy, 2015). However, while the complex relations between energy, society and power have begun to be theorised in these bodies of works, research and literature exploring the particular socio-political, spatial, as well as historical dimensions of energy and energy transitions remains scarce (Becker et al, 2016; Huber, 2015). This paper proposes a renewed focus on the histories, spatialities and political possibilities of energy geographies, which can bridge the gap between more (eco-) technical energy debates, and the, as yet, largely energy-distant political geographies (on the intersection of energy and urban studies, see: Rutherford \& Coutard, 2014). Thinking energy and political geographies in dialogue can allow for a more critical and in-depth exploration of energy transitions as dynamic, sociospatial and politically-contested phenomena, in which history, space and struggle are deeply entangled. The following section critically engages with recent work on energy transitions and stresses the need to examine the spatial politics of transitions projects. Proposing a sociohistorically sensitive analysis of energy transitions allows for transitions to be understood as 
politically contentious and socio-spatially constituted as much as eco-technical (see also: Huber, 2009). These deep entanglements of history, space and struggle are necessary to gain a richer, historically sensitive understanding of political contestation and struggle as part of energy transitions. In this context, the section also engages with literature on the political contestation of energy generation, infrastructures and organisation to introduce the notion of struggle, and more specifically energy struggles, as expressions of a critical ideological engagement with energy systems, energy spaces, and acts of socio-political spatial reimagining. Historical struggles, especially around energy, also play an important role in the imagination and narrative of present struggles. An emerging narrative of socio-political spatial reimagining will also be revisited in the final section of this paper, which explores recent calls for energy democracy as an expression of 'new' spatial politics of energy transitions, building on the multiple, evolving and dynamic struggles in and against contemporary energy systems.

In light of recent energy crisis discourses - an energy crisis of environmental limits and/ or through resource scarcity - many, if not most, governments have taken action to reduce their dependence on fossil fuels and consequently researched, developed and invested in low-carbon, and often renewable, energy sources as part of their respective energy transition portfolios. Recent work on energy transitions across Europe, especially the UK, Netherlands and Belgium, has largely focussed on an analysis of socio-technical factors of renewable or low-carbon energy transition management through multi-level perspective approaches (e.g. Geels, 2011; Loorbach \& Rotmans, 2010). Despite characterising transitions as 'socio-technical' the literature heavily relies on technical language to describe its "theory [of] a modular structure" to frame transition processes (Loorbach and Rotmans, 2010: 239, citing Meadowcroft). Human geographers have criticised the lack of attention to geographical 
concepts such as space, place and scale within such frameworks (Bridge et al, 2013; Coenen et al, 2012; Raven et al, 2012). Furthermore, transition management literature, while attentive to culture and ideology to a degree, lacks appreciation of the socio-cultural histories of, as well as the long-standing socio-political struggles, conflicts and acts of contestation within particular transition projects. Energy transitions are deeply embedded in wider socio-spatial developments, such as changing energy needs of post-industrial societies or shifting ideologies, for example through increased awareness of environmental issues. Existing transitions literature furthermore often suggests, or at least implicitly assumes, a false linearity and consensus within transition management, and fails to explore the contested nature and multi-actor landscapes of energy transition projects, past and present (see also: Bridge et al, 2013; Chatterton \& Cutler, 2008).

Historicising energy politics and transition pathways contributes to richer, more nuanced understandings of energy transitions, past and present, through emphasising the plural, dynamic and contested trajectories of transition. A historically sensitive approach to energy transition studies furthermore reveals the multitude of actors and their contentious political practices and struggles within and against transition projects. As the topic of energy has received more attention in public discourses and news media, it is also increasingly contested - a phenomenon that is described in German public discourse as Energiekämpfe, energy struggles. Müller (2013: 7) defines energy struggles as "social struggles over the control of, the access to, and pricing of energy [which] have always been, and increasingly are, at the core of social conflicts around distribution and ecology, modes of production and modes of life". Energy struggles have transformative potential, especially as they are expressions of a critical ideological engagement with energy and environmental topics, and collectively challenge the prioritisation of expert knowledges and technocratic arguments in 
public debates. Next to energy struggles more specifically, the notion of struggle generally facilitates a critical engagement between energy geographies, transition management studies and related social movements and struggles, including anti-capitalist, alternative ownership, democratic, and social and climate justice based demands. However, much recent work does not directly engage with the particular and dynamic histories of energy transition projects as well as the socio-political struggles that have contributed to the terms on which energy and energy transitions are experienced and contested in different places (Juisto, 2009).

Building on the strong tradition of interrogations of space and the political through the notion of contestation in human geography (Massey, 2005; Featherstone, 2013; see also: Featherstone \& Korf, 2012), an engagement with struggle, especially over energy, allows for a more critical understanding of existing and emergent spaces of energy transition. While literature on the geographies of political contestation has recently begun to link debates around neoliberalisation and the political to the environment (Beveridge et al, 2014; Chatterton et al, 2013; cf. Swyngedouw, 2009; 2010), there has been little work which specifically focusses on the political, contestation and energy (as well as transition projects). Existing engagements at the intersection of neoliberalisation, the political and the environment often focus on the political possibilities of acts of contestation for the emergence of alternative politics and governance models. Beveridge et al (2014) for example critically engage with post-political literatures to explore the implications, and potential political possibilities, of Berlin's water company's partial remunicipalisation in the context of neoliberal urban governance (see also: Kenis \& Lievens, 2014). Not wanting to endorse blind optimism for a post-neoliberal future, the authors nevertheless stress that acts of contestation and resistance to neoliberalism can and do prevail, in this case at the local scale, and advocate for a better spatialisation of political contestation (Beveridge et al, 2014; see also: Chatterton 
et al, 2013; Featherstone \& Korf, 2012). The notion of possibility is also invoked by Smith (2015), who, while only marginally dealing with the resource under contestation, powerfully explores the spatial politics and the diverse trajectories of struggle and resistance around mountaintop removal of coal in central Appalachia, USA. Smith's analysis of class power, gender and community in coal mining regions is framed through the history of spatial dispossession, stressing the need to understand Appalachia's history in order to trace the diverse trajectories of opposition today. Embracing these various engagements with political contestation, socio-cultural history and space, this paper argues that, to date, energy geographies literature mostly lacks a focus on the relation between energy spaces and energy struggles.

This paper advocates for a sensitivity towards the notion of struggle in human geographical engagements with (energy) transitions. While conflict, especially opposition to new developments, has been examined in the energy sector (e.g. Walker et al, 2010), the notion of struggle and the socio-cultural histories of contestation are under-researched in the context of transition projects. While 'conflict' can refer to various disputes in the energy sector (e.g. over fracking, or protest against windfarm installation in Wales, see: Mason \& Milbourne, 2014), the 'contestation' of, and (sometimes) resulting 'struggle' over, energy and transition projects more specifically refers to critical, socio-political expressions and practices through which resource questions are linked to broader questions of ownership and organisation. This broader conceptualisation of questions around energy has for example been addressed in emerging energy democracy discourses. Energy democracy, as both a recent concept and growing eco-political movement, emphasises the need to rethink energy systems in light of social justice and democratic accountability in order to create more sustainable energy future. While there are some notable exceptions (Angel, 2016; Becker \& Naumann, 
2017), energy democracy has received little attention in both energy and human geographical research to date, and agendas for research and practice are still in need of concretisation and further conceptualisation (Kunze \& Becker, 2014; Müller, 2013; Sweeney, 2013 [2012]). Angel (2016) for example stresses the need to address questions of state power as part of energy democracy demands and, in this context, explores the politics of the Berliner Energietisch as in-against-and-beyond the state (see also: Cumbers, 2015; Holloway, 2010). While comprehensively addressing the Energietisch's struggles in relation to the state, Angel (2016) only briefly touches on the rich history of energy struggle in Germany that contextualises contemporary contestation. Looking to the future, Müller (2013) emphasises the need to further explore the potential of the term 'energy democracy' to build a progressive movement around energy struggles, and to create a broad coalition of social actors from left, green, and democratic backgrounds. The democratisation of energy generation, resources and infrastructures, and its relevance to and implications for the socio-spatial politics of energy transition are further addressed in subsequent sections of this paper, especially section five.

While analyses with a sensitivity towards energy struggles are largely absent from human geographical enquiries, on a more general level, a recent article by Bridge et al (2013) proposes to explore the social implications of, and conflicts around energy generation and infrastructure through the lens of landscape theory. In this context, recent empirical work in Wales by Mason and Milbourne (2014; see also: Milbourne \& Mason, 2017) has also engaged with landscape, specifically the concept of landscape justice as a productive extension of existing environmental justice literature, to "analyse the spatialities and temporalities in discourses around windfarm development" (Mason \& Milbourne, 2014: 107). In a second article, the authors (Milbourne \& Mason, 2017) furthermore explore the potential of a 'right to landscape' through struggles against opencast coal mining in South Wales. 
However, while a focus on (energy) landscapes usefully reveals the interplay of natural, technical and cultural phenomena, it lacks an appreciation of the histories of struggle and contestation, which can contribute to richer analyses and accounts of energy transition practices. Milbourne and Mason's (2017) paper powerfully engages with the relationship between struggles for environmental justice and the geographical imaginations around landscape and place. However, while Wales's energy history is present throughout their paper, the particular kinds of intense historical struggle and contestation, for example during the 1984-85 Miners' strike when South Wales was one of the areas where support for the strike was strongest (Francis, 2009; Kelliher, 2017), could have been more clearly drawn out. Wales's history of mining, be that in form of underground or open cast mining, was highly contentious (Francis, 2009), and analyses of contemporary transition politics cannot be abstracted from such struggles of the past. Historical struggles continue to exist in activist imaginaries and are deeply interwoven with local imaginaries and narratives of energy, place and (in)justice. Considering the socio-political dimensions of energy transitions through a historically-sensitive analysis thus allows for an understanding of transitions as more than a switch between one method of energy generation to another. Instead, transitions can be conceptualised as resulting from, and being embedded in, broader socio-spatial, cultural, political and economic structures and processes, including (energy) struggles. To exemplify, while the decision for or against certain policies, such as feed-in tariffs, subsidies and exemptions can lead to very different transition outcomes (see: Huss, 2014; Nordensvärd \& Urban, 2015), these decisions are not made in a political vacuum and always reflect the particular socio-cultural and political struggles of their time (for a related discussion on rolling path-dependencies in post-socialist urban studies, see: Bouzarovski et al, 2016). Analyses and accounts of transition practices need to acknowledge socio-cultural histories, respective policy developments, and socio-political struggles around transition projects (in a 
German context, see: Beveridge \& Kern, 2013; Morris \& Jungjohann, 2016). Additionally, transitions are informed by past struggles and trajectories and cannot be read independent of, and abstracted from historical processes and tensions.

A historicisation of contentious politics and energy struggles facilitates a more empirically robust framing of energy transition projects as dynamic, multi-actor, and more than eco-technical processes. This paper thus extends Bridge et al's (2013: 339, emphasis in original) call for researchers to "understand how energy transitions are spatially-constituted", and calls for an understanding of transitions as socio-spatially constituted in order to be inclusive of past and present struggles. Historicising transitions can furthermore uncover the deeply entangled nature of narratives of struggle in broader understandings of energy transition projects today. This paper argues that experiences of past energy struggle(s) constitute both activist and civil society-based narratives and imaginaries of transition. Extending this line of argument, calls for energy democracy can also be understood as having emerged from a long and rich history of struggle and contestation around energy projects, infrastructure and resources. The following sections utilise empirical materials from the German Energiewende to explore the entanglements of history, society and space in energy transitions, before engaging with energy struggles as contentious practices, and exploring the emergent spaces of energy democracy in more depth.

\section{Exploring the Deep Entanglements of History, Space and Struggle in the German}

\section{Energiewende}

The Energiewende, often translated to 'energy transition', is a distinctly German development which evades straightforward definition (Beveridge \& Kern, 2013). While not necessarily 
wrong, the translation to 'energy transition' does not fully capture the more nuanced meanings of the German term, which places more emphasis on processual, sustainable and lasting changes to the energy (and wider environmental) status quo. Next to translative ambiguities, the Energiewende, as a term and project, has also been variously defined in German and international contexts. Contemporary framings for example closely associate the term Energiewende with Chancellor Angela Merkel's government's triple transformation transition project, which exists in its current form since 2011 (Röttgen, 2013; Schlögl, 2015). 'Merkel's Energiewende' includes a nuclear power phase-out, ambitious greenhouse gas emission reductions in line with international agreements, as well as energy efficiency goals which are to be achieved through building modernisation and a new mobility concept $-\mathrm{a}$ project widely hailed as "one of the most ambitious national energy transition initiatives worldwide" (Moss et al, 2014: 1; Röttgen, 2013), an assessment that German researchers have approached with caution (Haas \& Sander, 2016; Moss et al, 2014). Furthermore, the current conception as 'Merkel's Energiewende' has somewhat co-opted a broader, decadesold project, process and movement also known as Energiewende. As a movement, the Energiewende has a rich history of socio-political struggle and has produced key legislative successes, alternative organisational models for energy generation and ownership, as well as broader cultural attitudes and behavioural dynamics around environmental and energy issues within German civil society (Beveridge \& Kern, 2013; Moss et al, 2014, Schlögl, 2015). While the current transition from nuclear and fossil-based energy sources towards a lowcarbon energy future is an important and in many ways integral part of the broader Energiewende process, 'Merkel's Energiewende' could not have happened independently from four decades of socio-political movement building, struggle and contestation, as well as the policies that were developed before Merkel. The Energiewende thus needs to be understood through its rich histories and spatial politics - before, under and after Merkel. 
In June 2015, seven semi-structured, qualitative and in-depth interviews were conducted within the broader German left-green movement, which is working towards a socio-ecological restructuring of society as well as a just and democratic Energiewende. The project work was undertaken in Berlin, Germany, and explored the political and radical possibilities of energy struggles as part of the German Energiewende, past and present. Interviewees include activists, researchers and politicians involved with the Rosa Luxemburg Stiftung (Rosa Luxemburg Foundation), the Berliner Energietisch (Berlin Energy Roundtable), or Die Linke, the German Left Party; thus representing three, to varying degrees related organisations of the wider left-green movement in Germany. All participants are experts in the field and are actively involved in researching, shaping and/ or mobilising for left-green alternatives in their often overlapping roles as researchers, politicians and activists. When quoted in this paper, the interviewee's respective role and relationship with the case study organisations is highlighted to help position statements.

The primary case study partner for the project, the Rosa Luxemburg Stiftung, is a political civic education institution affiliated with the German Left Party and was chosen for its committed work towards socio-ecological restructuring and more radical alternative visions for a socially just and democratically accountable Energiewende. Based on this initial engagement with the Rosa Luxemburg Stiftung, the Berliner Energietisch campaign was chosen as a case example for a concrete energy democracy struggle, in which both the Rosa Luxemburg Stiftung and the Left Party Berlin were involved. The Berliner Energietisch campaigns for the remunicipalisation of Berlin's energy supply, which unites social and ecological justice demands in a novel public ownership framework. Upon first contact with the Rosa Luxemburg Stiftung, additional participants were identified utilising a purposive 
snowball sampling strategy, which follows a loosely existing network of interconnected actors, embedded, to varying degrees, in the wider leftist culture of Die Linke and the Rosa Luxemburg Stiftung in Berlin. The following section utilises some of the collected empirical materials from the interviews, as well as relevant 'grey' materials such as surveys, reports and articles by third sector organisations and campaign groups, to explore different cuts through the wider left-green movement, including the rich histories and spatial politics of the Energiewende. The remaining two sections in this paper engage with the notion of struggle as constituting energy transitions and the emergent spaces of energy democracy to highlight and explore the inherent socio-spatial character and contentious practices of energy transition politics.

The need to pay attention to the particular histories and spatialities of the Energiewende in order to understand its development and characteristics was continuously stressed by interviewees. In this context, participants also repeatedly referenced the importance of previous sets of legislation (or 'policies-before-Merkel') which help to contextualise the more recent developments as part of 'Merkel's Energiewende'. Here, especially the 1991 Stromeinspeisungsgesetz, the Electricity Feed-In Act, and it's 2000 extension and effective replacement, Erneuerbare-Energien-Gesetz (EEG), the Renewable Energies Act, are noteworthy. Implemented under the coalition government of the SPD (Social Democratic Party) and the Green Party through major efforts of SPD politician Hermann Scheer; the EEG is essentially an instrument of market control, which offers producers at all scales a guaranteed fixed price for the renewable energy they produce, thus making previously expensive alternative and renewable energy technologies more affordable to both industry and citizens. Despite being one of the cornerstones of today's energy politics in Germany, the EEG has faced uncertainty since its implementation as new governments 
took office. The EEG has also seen many revisions, including a 2014 amendment under Merkel, which undermines the participation of small-scale actors in renewable installation in favour of larger corporate entities:

\footnotetext{
"That's a conflict that has come to a head in recent years - on the one hand there are increasing attempts of big energy corporations to take over the Energiewende, to steer it into another direction and to slow it down at the same time. And that is reflected in increasing investments into offshore wind energy, which, on the other hand, are supported in the recent amendments to the EEG which make large-scale offshore investments more attractive." (Participant 7, independent researcher and writer for the Rosa Luxemburg Stiftung)
}

The recent developments in energy legislation can be understood in line with broader neoliberal politics and developments in the energy sector, and are in contrasts to previous versions of the EEG as envisioned and practiced under the red-green coalition of SPD and Greens (see also: Morris \& Jungjohann, 2016, chapter 13). This example highlights the precarious nature of environmental policies as well as the societal support and political will necessary to sustain them. The now well-known German nuclear phase out provides an example of how public opinion and societal support can influence environmental policymaking. Following the 2009 elections the new coalition government of CDU/CSU (the union of Christian democratic conservative parties) and FDP (the liberal Free Democratic Party), headed by Angela Merkel, attempted to extend nuclear plants' operational life spans past the originally agreed phase-out deadline, which was also established under the red-green coalition government of 1998 (Beveridge \& Kern, 2013; Huss, 2014; Schreurs, 2012). However, the Fukushima accident in 2011 triggered a similar civil society backlash-effect to 
that of the Chernobyl disaster 25 years earlier, and the liberal-conservative coalition government ultimately gave in to the pressure from civil society to return to politics of a structured phase-out with a new deadline of 2022 (Beveridge \& Kern, 2013; Morris \& Jungjohann, 2016; Röttgen, 2013):

"The attempt to reverse the nuclear phase-out [between 2009 and 2011] failed because Angela Merkel would have had to sail against the wind of public opinion in such a stark manner that she didn’t want to risk it.” (Participant 4, researcher for Rosa Luxemburg Stiftung)

Merkel's Energiewende should thus be understood as one expression of the larger Energiewende project rather than its defining element. Merkel's Energiewende exists alongside multiple historic and contemporary expressions of the Energiewende, which were and are put forward through different political parties and their respective agendas (e.g. previous legislation under the coalition of the SPD and the Green Party, 1998-2005), and from different social actors and movements (such as the Anti-Nuclear Movement and the broader environmental movement). These various expressions attempt to pull the direction of the Energiewende project towards different transition outcomes regarding ownership (public/municipal, private capital or cooperative), organisation (small or large scale, decentralised or centralised models), and resource preference (such as small-scale renewables, anti-nuclear, corporate offshore wind, etc.).

Any conceptualisation of the Energiewende is inseparable from wider political, societal and cultural contexts, such as political coalition efforts for renewable energy generation or civil society support of anti-nuclear legislation. Most importantly, however, the 
Energiewende cannot only be understood as a result of governmental strategy of one party or coalition alone, and has a wealth of meaning as a 'wider societal project' and movement with a considerable socio-cultural history. Participants especially stressed the importance to understand the Energiewende, including its legislative history, as a project and process that was made possible by civil society as much as by politicians and policy makers. Participant 3 , a politician for the left party Die Linke, emphasises that legislative changes in German energy politics have always corresponded with civil society engagement and activism:

\footnotetext{
"It is important that [the Energiewende] is understood as a societal constellation... one cannot explain the Energiewende simply through looking at the Bundestag [federal parliament] - that would fall short of reasonable explanation. The reasons for policy changes in parliament, first seen in majorities for the Stromeinspeisungsgesetz, later the success of the EEG, are reflections of what happened in society." (Participant 3, politician for Die Linke)
}

Building on this line of argument, a historico-cultural approach to the Energiewende and other transition projects, allows for a more conceptually-rich understanding of the origins, linkages and trajectories of energy transitions, and thus highlights the multifaceted and often contested nature of energy politics. The interviews within the left-green movement offered a range of historical and contemporary examples of activism and civil society involvement in Energiewende politics through drawing on a rich history of environmental and energy struggles in Germany. Civil society and social movements have been among the main drivers of the Energiewende from its very beginnings and the continued involvement and support of these groups in democratic and emancipatory processes continues to legitimise the project: 
"What we have here in Germany is a politicisation of energy - that will remain, it won't wear off. I think that is connected to this certain tradition and attitude we have here, that has been built up over 40 years and that I have not come across in this way in any other European country towards energy issues. The first protests against nuclear power stations in the late 1960s and beginning of the $1970 \mathrm{~s}-$ that is the origin of this whole movement that then manifested in the establishment of the Green Party, that eventually also - via the nuclear debate - crystallised into renewable energy movements, which were pushed for by citizens that simply set up the first renewable technologies in their backyards." (Participant 2, coordinator of Berliner Energietisch)

In the above quote, participant 2 refers to the longstanding German tradition of energy and environmental movement building beginning in the 1960s and 1970s when so-called 'backyard-pioneers' started to experiment with low-cost, innovative technologies for wind, solar and biogas energy, which were soon picked up by the growing environmental movement and anti-nuclear struggles. While Cumbers (2012) cites a similar process of a collective imagining of alternative, decentralised and specifically non-nuclear energy futures in Denmark, energy transition projects in other countries, such as France and the UK, often actively include nuclear power either as an alternative to fossil fuels or to bridge energy demands during transition periods. The German Energiewende, however, is closely aligned with the German Anti-Nuclear Movement, which was born out of an exceptionally strong anti-nuclear moment in the 1970s and is now deeply rooted in German culture and society (Mez, 2012; Özdemir, 2014; Schreurs, 2012). However, despite the undeniable strength of the movement, the accomplishment of the Atomausstieg, the nuclear phase-out, took another four decades to complete, facing political U-turns and requiring continuous and committed struggle and dedicated activism, including civil disobedience, broader civil society 
involvement, continued political 'lobbying' from below and two nuclear catastrophes. Through embedding the Energiewende within broader social movements as well wider social struggles, such as the anti-nuclear struggle, the larger environmental movement, the peace movement, as well as democratic struggles around the access to, and control over, energy generation and infrastructure (including remunicipalisation projects and cooperative initiatives), the Energiewende can be understood as holding transformative and emancipatory potential beyond the materialities of energy generation and infrastructure. Discussions around the materiality of energy production and consumption, for example the use of nuclear, coal or renewable energies, never exist in a policy-vacuum and were always linked to broader discussions around who decides over which kinds of energy are produced, how they are produced and where, which has added a clear socio-political and spatial dimension to energy struggles and debates. The fight against nuclear power, for example, can in many respects be understood as a fight for democracy and the right for frontline communities to meaningfully participate in decision-making processes. In this context, Morris and Jungjohann's (2016: 15) chapter on the first anti-nuclear protests in Wyhl, Germany, points out that early nuclear struggles did not emerge out of concerns over the safety of nuclear power but instead "against an authoritarian government and the arrogant technocrats who were trying to push through a large nuclear plant”.

The Energiewende is thus best defined as a long-term process, which is shaped through its particular socio-cultural histories and spatialities as well as the involvement of multiple actors across all sections of society. Essential to its development was and is German civil society, which has continuously challenged, shaped and legitimised the Energiewende through engaging in energy struggles, past and present. These energy struggles continue to hold political possibilities through challenging ownership and decision-making structures, 
including struggles around the resources used to generate energy (such as nuclear, and more recently, coal and lignite) as well as struggles relating to ownership and control over energy systems (such as remunicipalisation campaigns and cooperatives). Such struggles also address the spatial organisation of energy generation, infrastructure and consumption, and ultimately challenge the social production of energy spaces as well as the ways in which energy knowledges are produced.

\section{Energy Struggles as Contentious Practice}

As stressed in section 2, a sensitivity towards the notion of struggle, and especially energy struggle, is paramount to understand energy transitions past and present. Energy struggles are generally defined as social struggles over the control over and access to energy (Müller, 2013). As such, energy struggles have transformative potential; they are expressions of a critical engagement with the social production of energy spaces and collectively challenge the prioritisation of expert knowledges and technocratic discourses around energy and climate issues. The interviews offered multiple examples of energy struggles and the ways in which communities engage in and with them, ranging from larger struggles such as the Anti-Nuclear Movement to 'smaller', local struggles around the particularities and materialities of energy generation. The importance to pay attention to historical struggles is also emphasised by Müller (2011), who discusses the possibilities of mobilisation for a larger left-green project and stresses the potential of energy struggles for the Energiewende past and present. Müller (2011: 1) states: "what is described simply as Energiewende is actually a generic term for a multitude of energy struggles, on different scales, which are led by a multitude of actors through diverse means". Expressions of struggle as part of energy transition projects manifest themselves in two interrelated and important ways, firstly, as challenges towards expert and 
elite knowledge production, and secondly, as forms of critical engagement with the social production of energy spaces. Energy struggles, while often directed either against or for a certain resource, are not confined to the materialities of energy transitions alone and address wider social and political processes through challenging the ownership, control and decisionmaking structures that govern transition politics. Even the Anti-Nuclear Movement, which is often understood as a resource-based struggle focussing prominently on the phase-out of nuclear energies, has continuously engaged with broader social and political processes through actively challenging the decision-making structures for energy generation and infrastructure, the interests of the nuclear lobby, as well as unremittingly defending their gains against federal government intervention (such as Merkel's attempts to reverse previous phase-out politics). Energy struggles and past experiences of achievable change associated with energy politics in Germany's recent history have subsequently produced a discourse of energy as a political project, for which "a fundamental consensus [exists] that something is actually happening - at the moment a lot seems possible that even a few years ago would have been unimaginable", as one participant put it. Rather than echoing neoliberal discourses of persuaded helplessness or the lack of alternatives, the interviewees invoked the successes of recent movements, especially the Anti-Nuclear Movement in achieving the nuclear phaseout but also recent, local campaigns, such as remunicipalisation project, as a motivating factor for other struggles. Past and present energy struggles are thus tightly woven into an understanding of the German Energiewende as social and political movement, and past struggles are repeatedly invoked to organise, strategise and narrate present and future energy politics.

Experiences of struggle and contestation, as well as successful politicisation as part of the Anti-Nuclear Movement were also often invoked in the interviews to address and 
challenge expert knowledge-making in the energy sector, and more widely contest the terms through which energy, the environment and climate change are discussed:

\footnotetext{
"As the Anti-Nuclear Movement has shown, it is definitely not impossible to mobilise people and build up a social movement around issues of energy - back in the day the smallest number of people would have been able to explain to you exactly how and why a nuclear plant is unsafe in a certain location, but nevertheless many people got engaged and increasingly immersed in the topic, and it is the same for the Energiewende.” (Participant 4, researcher for Rosa Luxemburg Stiftung)
}

Challenges of expert and elite knowledge and decision-making have been a recurring feature in the history of the German Energiewende. These challenges happen at all kind of scales and address both the technocratic and expert-oriented discourses on energy issues as well as the governance of energy generation and infrastructure. The Anti-Nuclear Movement for example questioned the necessity for nuclear power in general, as well as continuously challenging top-down decision-making on, for example, the location of nuclear plants and questions of where and how to dispose of nuclear waste. Through addressing and engaging in concrete and practical debates around nuclear energies, the Anti-Nuclear Movement was also reclaiming the terms of debate on and through which nuclear power was attempted to be legitimised by the nuclear lobby and federal government (see also: Morris \& Jungjohann, 2016). While acknowledging that participation in debates around energy and environmental issues requires a certain level of knowledge, 'expertise', or at least analytical ability, interviewees nevertheless stressed that a lot of 'ordinary' people had committed to becoming experts in order to participate in, and change the direction of debates on nuclear energies rather than accepting top-down expert decision-making. This building of alternative 
knowledges and insistence on participation can also be found in Denmark, where, what Cumbers (2012: 200) aptly terms, a "thick civic and participatory culture" around energy decision-making has led to high levels of acceptance of windfarms and renewable energy developments (cf.: Mason \& Whitehead, 2014 on Wales where public participation in windfarm development is severely lacking). Another way in which people have become 'experts' in renewable and alternative technologies is and was through experimentation or backyard tinkering. Toke (2011: 73) for example understands the European Anti-Nuclear Movements as “strong 'industrial opposition movement $[\mathrm{s}]$ ' [...] whose demands for a technological substitute for nuclear power could not initially be fully resolved under the existing energy-industrial regime". Participant 3, a politician for Die Linke builds on early experimentation and collective learning to explain how, ultimately, a political movement took shape through which more people were encouraged to challenge top-down and expert knowledges around energy:

\footnotetext{
"And this breeding ground of thousands of tinkerers, backyard pioneers, small groups, initiatives, together with the growing - and strong - Anti-Nuclear Movement [...], it formed the societal foundation on which successive political decisions and energy policies have to be understood."
}

Contestations of expert knowledge making, an emphasis on participation and the resulting mobilisation of alternative 'experts' to challenge top-down energy politics emphasises the dynamic and plural histories of energy transitions and the deep entanglements of struggle and contestation as part of energy transition's spatial politics. The wish to participate in decisionmaking and to create alternative technologies, decision-making and ownership structures can now also be observed in renewable energy debates as well as broader Energiewende 
discussions, regarding questions of renewable energy capacity and location, grid and transmission challenges for wind and solar energies between the north and south of Germany, or in arguments for and against certain 'bridge fuels' to address the phase-out of nuclear energy (such as lignite). While levels of expertise obviously widely differ, German civil society has managed to reclaim some of these discourses from an expert-technical sphere back into the public-political sphere, thus facilitating more open and dynamic debates around energy issues, and ultimately creating more opportunities for participation in decision-making processes:

\footnotetext{
"There is widespread knowledge [of Energiewende issues] in Germany, also with nonexperts... so, people who do not engage with energy professionally can and do contribute to the debate as well." (Participant 1, independent researcher and writer for Rosa Luxemburg Stiftung)
}

Dynamic, multiple and civil society-led energy politics, as practised in the German Energiewende, have politicised energy policies and challenged elite decision-making for decades. The Energiewende has seen contestation of both the technologies and policies of energy transitions as well as of the 'sensible' or 'givens' of energy and broader environmental politics through experimentation, collective learning and activism (Chatterton et al, 2013; Featherstone, 2013; cf. Swyngedouw, 2009; 2010). Since the early 1970s, German civil society has engaged in a collective re-imagination of the technologies of energy generation and consumption, challenging nuclear power as well as increasingly coal and lignite mining through protest, activism and civil disobedient action. The 'spirit' of these past energy struggles and their political possibilities has produced more than four decades of critical engagement with aspects of energy and environmental politics and governance in Germany, 
and lives on today. An example of politicised energy struggles are the "Schönauer Stromrebellen", Schönau's energy rebels, referring to the citizens of the Black Forest town Schönau, who established the first national green municipal utility in the 1990s (for an overview in English see: Energy Democracy, WWWa; Morris \& Jungjohann, 2016). These and similar forms of engagement with, and debate around energy and participation have led to the emergence of 'new' energy spaces and discourses, such as recent calls for 'energy democracy'. Emergent calls for and spaces of energy democracy can be understood as expressions of a 'new' spatial politics of energy transitions, building on the multiple evolving and dynamic struggles in and against contemporary energy systems.

\section{Emergent Spaces of Energy Democracy}

Committed and continuous protest, civil disobedient action, and the active re-imagining of alternative ways of organising energy in society as practiced by German civil society can be understood as examples of critical engagement with the construction of energy spaces through energy struggle. Over the past two decades, such energy struggles and act of reimagining have led to the emergence of alternative ownership and decision-making models in the German energy sector, particularly in relation to electricity production and consumption (Moss et al, 2014). While a range of alternative ownership practices have been developed and realised, including municipal utilities, energy cooperatives, eco-villages, transition towns, and the remunicipalisation of energy infrastructure, two models of decentralised and democratic energy ownership stand out in the German energy sector - citizens' cooperatives and remunicipalisation campaigns (Becker \& Kunze, 2014; Becker et al, 2015; Moss et al, 2014). The increasing popularity of remunicipalisation models, which include both the creation of municipal utilities and the remunicipalisation of transmission grids, has a significant impact 
on German electricity ownership, the majority of which is now in public hands (Hall et al, 2013). The emergence of alternative energy models and practices directly challenges the 'givens' of corporate energy ownership and the lack of democratic control over and participation in energy politics by the public. Energy struggles and the resulting alternative forms of energy organisation and ownership have clear spatial characteristics and political implications, which were often addressed in the interviews:

"These [energy] conflicts and struggles happen at all kinds of scales, beginning with struggles for remunicipalisation that we have just experienced in Berlin, to the longterm struggles for a nuclear power phase-out, now increasingly also the struggles for a coal power phase-out and against coal-mining, the renewable energies... so on the one hand there are powers that attempt to trigger changes which leads to more conflicts on the local scales on matters of where and how new forms of energy generation and infrastructure are being established.” (Participant 6, activist for Berliner Energietisch)

As participant 6 notes, the scalar character and spatial politics of transitions are tightly interlinked with energy struggles and conflicts in the German Energiewende. In a recent paper, Becker et al (2016) identify the production of space as key to develop a deeper spatial understanding of energy transitions. Participant 6's quote (above) taps into theories on the production of space, and conceptualises spatial structures as inherently co-produced with socio-political contestation and dynamic relations between actors. This interplay of society, struggle, space and energy has led to new forms of engagements with energy systems in the German Energiewende context. From a left-green perspective, these new terms of engagements have been framed as 'energy democracy', a recent movement to democratise energy generation, infrastructure and consumption through allowing more public 
participation and decision-making power. As introduced in the literature section, energy democracy demands politicise the spatial and material aspects of energy geographies and actively shape and challenge existing energy spaces.

The increasing remunicipalisation of energy generation and infrastructures can create opportunities for heightened levels of participation and democratic control as well as the possibility to introduce certain social, environmental and democratic components in the energy system of a region or city, such as graduated tariffs or price controls, renewable energy commitments and increased participation from members of the community. Remunicipalisations have much transformative potential, especially for more democratic control over, and public participation in, (decentralised) energy decision-making and more socially just energy systems. However, it is also important to stress that a change of ownership does not necessarily lead to more opportunities of public participation, democratic control or social justice and could merely result in a continuation of existing neoliberal financial practices (Becker et al, 2015; Höffler et al, 2013). 'Progressive' intent thus needs to be actively incorporated in, and addressed through civil society and activism for remunicipalisation campaigns. The case of the Berliner Energietisch is noteworthy here as the initiative was run under an energy democracy framework, which actively politicised energy generation and infrastructure and challenged undemocratic and socially unjust organisational and decision-making structures as part of Berlin's energy supply. In this context, a survey of energy democracy initiatives in Europe published by the Rosa Luxemburg Foundation's Brussels Office (Kunze \& Becker, 2014: 16) also notes that the Berliner Energietisch, if successful as an initiative, would have set a precedent in Europe by owning an "ecological and social community-owned [energy] supplier [...] [which] would have barred renewed privatisation" (see also: Attac, BürgerBegehren Klimaschutz \& Power 
Shift, 2011). However, and despite it's defeat, through adopting an 'energy democracy' framework, the Berliner Energietisch was able to move the debates around Berlin's energy system away from technical aspects of energy governance towards a reimagining of more emancipatory, environmentally and socially just, and democratically accountable energy futures. Energy itself becomes actively politicised as a socio-political and spatial relation which is more than an eco-technical issue, linking together a variety of actors and movements in a collective struggle. Participant 5, a researcher employed by the Rosa Luxemburg Stiftung, put it this way:

\footnotetext{
"Through linking the Energiewende and energy struggles to the term energy democracy we were able to create a signifier around which we can construct a larger movement - including the social struggles for democracy, the Energiewendemovements, and certain parts of the trade union and labour movement. This is partly because the idea of democracy is in a sense always a tool to nullify conflicts of interest. Because - how do you unite the structurally different interests of trade unions and radical greenies? It's easy; you chant the spell of 'democracy'... On some point I realised that the term had exactly that effect on me - because democracy is great, isn't it?"
}

Energy democracy provides both a counter-narrative and alternative discourse to other possible, but less emancipatory energy futures. Such alternative energy futures could for example be characterised by the introduction of higher prices for energy to encourage conservation while discouraging demand, which however further marginalises less privileged social groups, or manifest themselves in form of a mere eco-technical transition to renewable energy in which organisational and ownership structures remain as they are now - 
centralised, oligarchic and profit-driven. The term and concept of 'energy democracy' was first used in the context of the climate justice movement; the activist group gegenstrom defines it as "a concept capable of integrating energy and climate struggles [which] is grounded in the basic understanding that the decisions that shape our lives should be established jointly and without regard to the principle of profit" (cited in: Kunze \& Becker, 2014: 8). Energy democracy itself can be understood as the spatial politics of energy transitions, which, in its German form, has emerged out of a long and rich history of struggle and contestation as part of the German Energiewende. Energy democracy unites demands for a decentralised, democratic, renewable, and socially just energy future. As participants have pointed out, the concept shows potential to become a strong alternative to more top-down, centralised and neoliberal conceptualisations of the Energiewende, as well as to create a link between like-minded movements and groups in Europe and across the world. In this context, participants especially stressed the need for a 'scaling up' of, so far, still mainly local or municipal energy democracy initiatives, such as the Berliner Energietisch and energy cooperatives, to affect broader changes on both national and European scales:

"Irrespective of how you act on the local scale, on some point you reach a point where it is relatively obvious that whatever happens on the European scale will also affect the local scale. Accordingly, attempts are made to advance networks, exchange information cooperatively, as well as deploy lobbyist strategies [within the EU framework $[\ldots]$ it is a multi-scalar process - so, real implementation on the local scale so far but the national and European scales are also vital.” (Participant 7, independent researcher and writer for Rosa Luxemburg Stiftung)

Articulations of energy democracy as a spatial politics of transition allow for the 
Energiewende to be conceptualised as a dynamic, pluralistic and contentious process and movement, in which energy struggles exist in different places and at different scales. An energy democracy framework recognises the scalar and spatial politics of transitions to be dynamic and multiple. In this context, the Berliner Energietisch initiative provided a novel framework for a concrete energy democracy project through a remunicipalisation campaign. The initiative brought together different actors and groups, successfully identified and made use of a window of opportunity, and created a site of politicisation of energy issues in order to create a narrative of an alternative energy future for Berlin (Attac, BürgerBegehren Klimaschutz \& Power Shift, 2011; Wenderlich, 2013). Though ultimately narrowly defeated in the referendum, the initiative is a valuable counter-narrative to top-down energy politics and exemplifies the possibilities of political contestation as well as the deep entanglements of history, space and struggle in the social production of energy geographies and transition projects. These deep entanglements play out in various ways; spatially as based in Berlin, the 'capital of crisis' - a place both contentious and conform - (Beveridge et al, 2014), historically at the conjuncture of different legacies from both sides of the Cold War, and socially and politically, through a mobilisation of various social actors and movements on the progressive left. The Berliner Energietisch more specifically emerged from the entanglements of the previous successful struggle against water privatisation in Berlin, the Berliner Wassertisch, and the critical networks and coalitions this struggle had established in the city (Beveridge et al, 2014; Becker et al, 2015), as well as from the broader history and context of the Energiewende, as societal movement and project, constituted through energy struggles past and present. As one participant put it: "The Energietisch was an attempt to create real energy democracy now" (Participant 5, researcher for Rosa Luxemburg Stiftung). 


\section{Conclusion}

This paper has contributed to recent debates in energy geographies, and energy transitions, by developing a more critically and empirically grounded understanding of energy transitions as expressions of contentious socio-spatial politics, past and present. In particular, the thinkingtogether of energy and the political is explored through examining the role of energy struggles as part of transition trajectories and reflecting on the emergent spaces of energy democracy as a spatial politics of transition through a detailed discussion of the Energiewende. The entanglements of history, space and struggle thus become important dimensions for the study of transition dynamics and help further debates within energy geography as outlined in the literature section. Based on both a critical review of conceptual approaches and the discussion of empirical evidence, this paper offers three aspects in particular that can contribute to more critical and historically sensitive geographies of energy transitions:

Firstly, utilising an empirically robust and historically sensitive analysis of the German Energiewende, the paper has explored the deep entanglements of history, space and struggle in energy transitions. Transition projects such as the German Energiewende have long and rich histories of socio-political struggle and are the product of multi-actor, and often contentious, engagements with the social production of energy spaces. A historically sensitive and empirically rich analysis of transition projects facilitates a better understanding of energy transitions as socio-spatially constituted and allows for more dynamic and plural conceptions of transition trajectories.

Secondly, the paper has stressed the need to understand energy transitions as constituted by energy struggles and contentious politics, past and present. Energy struggles tie in with 
broader social movements, challenging decision-making structures and knowledge production as well as critically engaging with the organisation and ownership of energy in society. The notion of 'struggle' itself is interesting as it accentuates a critical ideological, even contentious, engagement with the (neoliberal) energy status quo. Focussing on the relation between energy spaces and energy struggles, past and present, opens up possibilities for more socio-political analyses of transition trajectories.

Thirdly, the paper has explored recent energy democracy demands as a spatial politics of energy transitions. Energy democracy presents an alternative discourse and spatial imagination for the energy sector, uniting demands for social justice, democratic accountability and environmental sustainability in the energy sector. Energy democracy itself can be understood as an expression of a new spatial politics of energy transitions, which has emerged out of the rich history of energy struggle and contestation as part of the German Energiewende. Emergent spaces of energy democracy, such as remunicipalisation models, cooperatives or the Berliner Energietisch initiative, provide both alternative spatial imaginaries and practices, and can challenge narrow conceptions of the political through providing more dynamic and plural understandings of energy transitions.

\section{References}

Angel, J. 2016. Towards an Energy Politics In-Against-and-Beyond the State: Berlin's Struggle for Energy Democracy. Antipode, early view. DOI: 10.111/anti.12289

Attac, BürgerBegehren Klimaschutz \& Power Shift. 2011. Neue Energie Für Berlin - Netze 
in Bürgerhand [New energy for Berlin - grids in public ownership]. Berlin, $2^{\text {nd }}$ edition.

Becker, S., Beveridge, R. \& Naumann, M. 2015. Remunicipalization in German cities: contesting neo-liberalism and reimagining urban governance? Space and Polity,19(1): 76-90

Becker, S. \& Kunze, C. 2014. Transcending community energy: collective and politically motivated projects in renewable energy (CPE) across Europe. People, Place and Policy, 8(3): $180-191$

Becker, S., Moss, T. \& Naumann, M. 2016. The Importance of Space: Towards a SocioMaterial and Political Geography of Energy Transitions. In: Gailing, L. \& Moss, T. Conceptualizing Germany's Energy Transition. Chapter 6. DOI: 10.1057/978-1-137-505934_6

Becker, S. \& Naumann, M. 2017. Energy democracy: Mapping the debate on energy alternatives. Geography Compass, 11(8), DOI: 10.1111/gec3.12321

Beveridge, R., Hüesker, F. \& Naumann, M. 2014. From post-politics to a politics of possibility? Unravelling the privatization of the Berlin Water Company. Geoforum, 51: 66-74

Beveridge, R. \& Kern, K. 2013. The 'Energiewende' in Germany: Background, Development and Future Challenges. Renewable Energy Law and Policy Review, 4(1): 3-12

Bouzarovski, S., Sýkora, L. \& Matoušek, R. 2016. Locked-in post-socialism: rolling path dependencies in Liberec's district heating system. Eurasian Geography and Economics, 57(45): $624-642$ 
Bridge, G. 2015. Energy (in)security: world-making in an age of scarcity. The Geographical Journal, 181(4): 328-339

Bridge, G., Bouzarovski, S., Bradshaw, M. \& Eyre, N. 2013. Geographies of energy transition: Space, place and the low-carbon economy. Energy Policy, 53: 331-340

Castree, N. 2008a. Neoliberalising Nature: The Logics of Deregulation and Reregulation. Environment and Planning A, 40: 131-152

Castree, N. 2008b. Neoliberalising Nature: Processes, Effects, and Evaluations. Environment and Planning A, 40: 153-173

Chatterton, P. \& Cutler, A. 2008. The Rocky Road to a Real Transition: The Transition Towns Movement and What It Mean for Social Change. Trapese Collective.

Chatterton, P., Featherstone, D. \& Routledge, P. 2013. Articulating Climate Justice in Copenhagen: Antagonism, the Commons, and Solidarity. Antipode, 45(3): 602-620

Coenen, L., Benneworth, P. \& Truffer, B. 2012. Toward a Spatial Perspective on Sustainability Transitions. Research Policy, 41 (6): 968-979

Cumbers, A. 2012. Reclaiming Public Ownership: Making Space for Economic Democracy. London: Zed Books, Chapter 9, pp.192-210 
Cumbers, A. 2015. Constructing a global commons in, against and beyond the state. State and Polity, 19(1): 62-75

Energy Democracy, WWWa. Elektrizitätswerke Schönau, Germany. Online available from: http://www.energy-democracy.net/?p=1067 [Accessed 29/01/2018]

Featherstone, D. 2013. The Contested Politics of Climate Change and the Crisis of Neoliberalism. ACME: An International E-Journal for Critical Geographies. 12(1): 44-64

Featherstone, D. \& Korf, B. 2012. Introduction: space, contestation and the political. Geoforum, 43(4): 663-668

Francis, H. 2009. History on our Side: Wales and the 1984-85 Miners' Strike. Ferryside, UK: Iconau.

Geels, F. 2011. The multi-level perspective on sustainability transitions: Responses to seven criticisms. Environmental Innovation and Societal Transitions, 1: 24-40

Hall, D., Lobina, E. \& Terhorst, P. 2013. Re-municipalisation in the early twenty-first century: water in France and energy in Germany. International Review of Applied Economics, 27(2): 193-214

Hargreaves, T., Hielscher, S., Seyfang, G. \& Smith, A. 2013. Grassroots innovations in community energy: The role of intermediaries in niche development. Global Environmental Change, 23: 868-880 
Haas, T. \& Sander, H. 2016. Shortcomings and Perspectives of the German Energiewende. Socialism \& Democracy, 30(2): 121-143

Höffler, F., Schäfer, C., Papenfuß, U., Rosenfeld, M. \& Landsberg, G. 2013.

Rekommunalisierung: Renaissance öffentlicher Unternehmen? [Remunicipalisation: A renaissance of public enterprises?] Zeitgespräch, DOI: 10.1007/s10273-013-1489-1

Holloway, J. 2010. Cracking Capitalism. London: Pluto.

Huber, M. 2009. Energizing historical materialism: Fossil fuels, space and the capitalist mode of production. Geoforum, 40(1): 105-115

Huber, M. 2015. Theorizing Energy Geographies. Geography Compass, 1-12, DOI: $10.1111 /$ gec3.12214

Huss, C. 2014. Energy Transition by Conviction or by Surprise? Environmental Policy from 2009 to 2013. German Politics, 23(4): 430-445

Juisto, S. 2009. Energy Transformations and Geographic Research. In: Castree, N. A Companion to Environmental Geography. Wiley-Blackwell, Chapter 31, pp. 533-551

Kenis, A. \& Lievens, M. 2014. Searching for 'the political' in environmental politics. Environmental Politics, 23(4): 531-548 
Kelliher, D. 2017. Constructing a Culture of Solidarity: London and the British Coalfields in the Long 1970s. Antipode, 49(1): 106-124

Kunze, C. \& Becker, S. 2014. Energy Democracy in Europe: a survey and outlook. Rosa Luxemburg Stiftung: Brussels Office. Available online:

https://www.rosalux.de/publication/40662/energy-democracy-in-europe.html [Accessed 21/02/2017]

Loorbach, D. \& Rotmans, J. 2010. The practice of transition management: Examples and lessons from four distinct cases. Futures, 42: 237-246

Massey, D. 2005. For Space. London: Sage.

Mason, K. \& Milbourne, P. 2014. Constructing a 'landscape justice' for windfarm development: The case of Nant Y Moch, Wales. Geoforum, 53: 104-115

McCarthy, J. 2015. A socioecological fix to capitalist crisis and climate change? The possibilities and limits of renewable energy. Environment and Planning A, 47: 2485-2502

Mez, L. 2012. Germany's merger of energy and climate change policy. Bulletin of the Atomic Scientists, 68(6): 22-29

Milbourne, P. \& Mason, K. 2017. Environmental injustice and post-colonial environmentalism: Opencast coal mining, landscape and place. Environment and Planning A, 49(1): $29-46$ 
Morris, C. \& Jungjohann, A. 2016. Energy Democracy: Germany's Energiewende to Renewables. Palgrave Macmillan, DOI 10.1007/978-3-319-31891-2

Moss, T., Becker, S. \& Naumann, M. 2014. Whose energy transition is it, anyway? Organisation and ownership of the Energiewende in villages, cities and regions. Local Environment: The Journal of Justice and Sustainability, DOI:

$10.1080 / 13549839.2014 .915799$

Müller, T. 2011. Von der Klimagerechtigkeit zur Energiedemokratie: Für's Klima kämpfen, ohne vom Klima zu reden. [Online] Available from:

<http://www.bdwi.de/forum/archiv/uebersicht/5415876.html> [Accessed 29/3/15]

Müller, T. 2013. Von Energiekämpfen, Energiewende und Energiedemokratie. Zeitschrift LuXemburg: Gesellschaftsanalyse und linke Praxis. Volume 1/2012, Energiekämpfe, pp. 615. English version online available from: <http://www.zeitschrift-luxemburg.de/of-energystruggles-energy-transitions-and-energy-democracy1/> [Accessed 25/8/15]

Nordensvärd, J. \& Urban, F. 2015. The stuttering energy transition in Germany: Wind energy policy and feed-in tariff lock-in. Energy Policy, 82: 156-165

Özdemir, C. 2014. The Need for Momentum in Europe's Climate Change Policies: Experiences from Germany's Energiewende. Global Policy, 5(1): 52-54

Raven, R., Schot, J. \& Berkhout, F. 2012. Space and Scale in Socio-technical Transitions. 
Environmental Innovation and Societal Transitions, 4: 63-78

Röttgen, N. 2013. 'Walking the Walk': a Snapshot of Germany's Energiewende. Global Policy, 4(2): 220-222

Rutherford, J. \& Coutard, O. 2014. Urban Energy Transitions: Places, Processes and Politics of Socio-technical Change. Urban Studies, 51(7): 1353-1377

Schlögl, R. 2015. The Revolution Continues: Energiewende 2.0. Angewandte Chemie International Edition, 54: 4436-4439

Schreurs, M. 2012. The politics of phase-out. Bulletin of the Atomic Scientists, 68(6): 30-41

Seyfang, G., Hielscher, S., Hargreaves, T., Martiskainen, M. \& Smith, A. 2014. A grassroots sustainable energy niche? Reflections on community energy in the UK. Environmental Innovations and Societal Transitions, 13: 21-44

Smith, B. 2015. Another Place is Possible? Labor Geography, Spatial Dispossession, and Gendered Resistance in Central Appalachia. Annals of the Association of American Geographers, 105(3): 567-582

Sweeney, S. 2013 [2012]. Resist, Reclaim, Restructure: Unions and the Struggle for Energy Democracy. Trade Unions for Energy Democracy, Cornell University IRL School - The Worker Institute \& Rosa Luxemburg Stiftung - New York Office: New York City, USA. 
Swyngedouw, E. 2009. The Anatomies of the Postpolitical City: In Search of a Democratic Politics of Environmental Production. International Journal of Urban and Regional Research, 33(3): 601-620

Swyngedouw, E. 2010. Apocalypse Forever? Post-Political Populism and the Spectre of Climate Change. Theory, Culture \& Society, 27(2-3): 213-232

Toke, D. 2011. Ecological modernisation, social movements and renewable energy. Environmental Politics, 20(1): 60-77

Walker, G., Devine-Wright, P., Hunter, S., High, H. \& Evans, B. 2010. Trust and community: exploring the meanings, contexts and dynamics of community renewable energy. Energy Policy, 38: 2655-2663

Wenderlich, M. 2013. Gaining public ownership of electricity in Berlin. Municipal Services Project. Online available from: http://www.municipalservicesproject.org/blog/gaining-public-

o

W

n

e

r

S

h

i

$\mathrm{p}$

e 